\title{
The First Steps in the State Systematization of Special Education: Ukrainian Experience
}

\author{
Natalia Dichek
}

The paper will substantiate the author's version of the retrospective analysis of the organizing in Ukraine in the 1920s-1930s the first state education system for the special children (the disabled), that is, children with physical or mental problems - blind, deaf, persons with mental or psychoneurotic problems. It is substantiated that for the first time in the history of national education, the state approach to the examination and selection, training, education, socialization or care of such children were legalized. In addition to specialized classes and boarding schools, the system of institutions for special children also included sanatorium schools, clinic schools, and speech therapy courses. During this period of time, a network of research institutions was also created - medical and pedagogical offices (1922), departments at the Ukrainian Research Institute of Pedagogy (1926) and the Ukrainian Psychoneurological Institute (1922), whose researches were engaged in the study of the special children and the development of methods for their rebabilitation training and possible correction of the bealth state. From the very beginning, the problem of the special children was considered in the unity of the pedagogical and medical aspects.

Keywords: children with physical or mental problems, pedology (experimental pedagogy), social upbringing, correctional pedagogy, Ukraine.

Ukraine has more than a century of experience in the education, upbringing, pedagogical and medical support of children and youth with special needs, as well as considerable experience in correctional rehabilitation for the various categories of children and adolescents who have mental and physical disabilities and, therefore, are in need of special psychological and pedagogical conditions for learning and socialization. The organization of the state special education system dates back to the tumultuous 1920s. At that time, defectology as a separate scientific branch began to develop in Ukraine. In today's scientific and pedagogical terms, it is special or correctional pedagogy. 
Nowadays, in Ukraine, based on child-centered principles and in the spirit of international conventions and UN pacts on human rights and the rights of people with disabilities $(1975$ - 2017), the educational principles of inclusive education are being implemented as a new step towards improving educational opportunities for special children ${ }^{1}$. In this respect, it is expedient to give a generalized overview in the historical retrospective of Ukrainian scientists' achievements in the field of special pedagogy forming the backbone of recent innovations in the field of the education of young people with special educational needs.

The study of the history of the development of special education ideas and practice in Ukraine was of interest to several Ukrainian researchers. The development of domestic experimental pedagogy and related special education issues were considered by V. Lukianova (2002), M. Popov (2007); special education teachers' training was covered by Vit. Bondar, V. Zolotoverkh (2003), O. Shevchenko (2004); the development of the education system in Ukraine for children with hearing impairments was studied by O. Taranchenko (2006; 2013), M. Yarmachenko (1976); the formation of speech pathologists' postgraduate education was studied by V. Hladush (2007), the development of correctional education for children with mental disabilities was represented by L. Odinchenko (1998), M. Suprun (2011), I. Kravchenko (2016). However, all the above-mentioned scientists addressed individual and narrowly specialized aspects related to the subject of correctional pedagogy. Therefore, there are grounds to carry out a historical and pedagogical retrospective of the problem of creating a system of education for special children in Ukraine on the socio-historical background of the 1920-1930s.

Up until the beginning of the 1920s, there was a very small number of private or charitable institutions in Ukraine, where children with hearing, vision and mental problems were cared for (Bondar, 1992, 2004, 2015; Yarmachenko, 1975). Enthusiastic educators provided them

\footnotetext{
${ }^{1}$ With Ukraine's accession to the International Convention on the Rights of Persons with Disabilities (2006), the use of terms that «degrade the dignity and worth of a person with mental and physical disabilities» (Convention on the Rights of Persons with Disabilities, 2010) is considered inhumane and unacceptable (Azin, Baida ...\& Fletcher, 2015, p.9). For tolerance reasons, we will use the term «special» children, but in quoting historical sources, we will stick to the terms used by the authors of that time.We should also add that in the English texts of modern official international documents on human rights and the rights of persons with disabilities, it is used the term a «person with disabilities», while in the legislative documents of Ukraine, it is still common to use the term «invalid», which is a Latin analogue, or an even more tolerant term «person (child) with a disability».
} 
with basic knowledge and taught certain craft skills to the extent to which it was possible. Such individual institutions operated on an initiative basis (Bondar, 1992, 2015; Suprun, 2005; Yarmachenko, 1975). Only in the 1920s, with an attempt to build in Ukraine (historically more precisely the USSR) a welfare state, for the first time in the history of its education throughout the country, systematic measures to organize care and education for children with mental and physical disabilities were introduced. A balanced differentiation of children was initiated, taking into account the psycho-physiological and age features of their body formation and the ability to learn. The individualization of children's education and upbringing at that time became widespread in the form of educational process pedologization.

Developing as an integral and experimental science about children, pedology was an international phenomenon of the first decades of the twentieth century. Regarding the problem of special children, Ukrainian pedagogues argued that by «treating a person's objective experience, their behavior and reflexes with certain pathological tendencies as a basis for a defective child's education and training», pathological pedagogy «becomes orthopedic reflexology with the main purpose to bring up connecting reflexes retarding, remedying and correcting the revealed defects» (Kozlov, 1928, p. 124).

That is, they grounded their research on socio-biogenetic principles. Human behavior was considered as a set of appropriate reactions of the body to various stimuli coming from the environment. So, each child has a certain set of reactions that ensures their adaptation to the environment. Therefore, «the biological basis of behavior, that is, reactions and their physiological mechanisms» should be studied (Protopopov, 1928, p. 195).

In the context of the educational process, this has been transformed into a statement that a teacher or educator must take into account all the kinds of children's reactions including human activity forms (handicrafts, dramatization, drawing, modeling, etc.).

However, for the completeness of the historical retrospective, it is necessary to take into account the scientific and pedagogical preconditions that enabled the development of an individualized approach to the education of special children and youth as well as to the organization of their lives. The prerequisites and driving force for the implementation of this approach at that time were the significant achievements of experimental pedagogy rooted in Europe and the Russian Empire in the second half of the nineteenth century. The studies by V. Bekhterev, O. Lazurskyi, M. Lanhe, P. Leshaft, V. Kashchenko, O. Nechaev, M. Rumiantsev, I. Sikorskyi, as well as such foreign scientists' findings as A. Binet, D. Burneville, E. Clapareda, E. Krepelin, 
M. Montessori, E. Meiman, G. Richard, T. Simon, S. Hall were among the most important ones.

In their studies, the issues of determining and taking into account the individual developmental characteristics (physiological, mental, sociopsychological) of healthy children and children with psychophysical development problems were raised: the adaptation of the learning process to the existing, genetic capabilities of the child; the features of children with mental and physical disabilities and the search for opportunities for compensatory education and training; the elimination of the troubled youth problem. Important scientific ideas were actively disseminated and implemented in the Ukrainian lands of the Russian Empire.

The development of certain medical and educational issues was carried out mainly on the basis of interested teachers' personal initiative at universities in Kharkiv, Kyiv and Odesa, as well as due to the efforts of teachers, enthusiasts and public figures concerned with cultural and educational development (Popiv, 1929, p. 130).

And although until the early 1920s, much was done in the study and episodic effective implementation of experimental research findings related to special children, there was a lack of consistency and connection between scientists and philanthropists-practitioners' individual efforts (Bondar, 1992; Dichek, 2013; Yarmachenko, 1975). The organization and operation of educational institutions for special children depended entirely on the initiative of financial benefactors.

Until the early 1920s, in Ukraine, there were no state scientific institutions conducting systematic research on pedagogy (Popiv, 1929, p. 130), including special pedagogy, just as there was no network of state educational institutions for children with psychophysical development disorders. Even in the days of the Russian Empire, there was an urgent need to create a state system of social assistance to children with mental and physical disabilities which would provide them with education, upbringing and treatment in special institutions, as well as the comprehensive study of such children. These issues were reputedly addressed and emphasized at meetings and conferences, in scientific publications by I. Sikorsky, V. Kashchenko, H. Troshyn, A. Vladymyrskyi, O. Shcherbyna, P. Melnikov, V. Vetukhov, M. Kotelnikov and others (Dichek, 2013). However, at that time the authorities failed to meet the needs of special children.

Back in early 1920, one of the initiators of pedagogical process modernization on a child-centered basis, Ukrainian pedologist O. Popiv in the program work «Declaration of the People's Commissariat of Education 
(hereinafter - PCE) of the USSR on children's social education ${ }^{2} \gg$ outlined the rural and worker authorities' intentions to change approaches to the education and upbringing of children. He wrote that, organizing a new «educational system of social education», the task was to realize the pedological and pedagogical dream - to project the right education onto the whole life of each child and to finally realize «their rights» (Popiv, 2003, p. 238).

Therefore, the idea proclaimed in the mentioned document that «care should be provided to all children, including sick, mentally defective, «child offenders» and the groups of children requiring a special educational approach» (Popiv, 2003, p. 239) became fundamentally important.

It should be noted that the «Code of Laws on Public Education» adopted in 1922 in the USSR already approved the division of all children in the country into certain groups according to the state of their physical and psychophysical development (Code of Laws, 1922, p. 30-31). «Normal» and «defective» children were singled out, and therefore the need for the establishment of educational institutions for physically, mentally and morally defective children alongside educational institutions for normal (average) children was recognized. Responsibility for the operation of such institutions rested with the Ministry of Education (at that time, the PCE of the USSR) and the Ministry of Health (at that time, the PCHC of the USSR).

According to the type of children's development anomalies, they were divided into three subgroups (those who are blind, deaf, with mental problems), and the state recognized the need to ensure «the interests of each of these groups of children» (Code of Laws, 1922, p. 31). An important role was also played by the mass registration of the entire child population of the USSR, which helped to identify children in need of special living conditions and education (Code of Laws, 1922).

Thus, from the beginning of the 1920s, the problems of raising special children began to be considered and solved in Ukraine at the national level as

\footnotetext{
${ }^{2}$ The meaning of the term «social education» in the 1920s reflected the attempt of the new state to educate a new generation of proletarians mainly by means of the influence of the new workers and peasants' society, and to significantly reduce the educational role of the family as a bearer of old, petty-bourgeois traditions. As early as in the late 1920s, this attitude toward the family was recognized as erroneous, and the term «social education» took on a meaning close to the modern interpretation referring to the relatively controlled socialization of the individual in the conditions of specially created educational institutions. The term «defective child «was common in both the Soviet and European scientific and educational space at least until the 1960s and was used to refer to children with various disabilities. The term «morally defective» child was widely used in Europe to refer to child offenders, homeless children but only until the 1930s.
} 
an urgent medical and pedagogical task. For this purpose, in accordance with paragraphs 255-261 of the «Code of the Laws of the USSR on Public Education» for the first time in four major cities of Ukraine - in Kharkiv (the capital of the USSR at that time), Kyiv, Odesa and Dnepropetrovsk - medical and pedagogical cabinets were created (hereinafter - MPC) that were aimed at: 1) conducting scientific examinations of the physical and spiritual nature of the child who visits such a cabinet; 2) scientific and experimental development of operational and organizational issues arising in the operation of institutions for children with special needs» (Code of Laws, 1922, p. 30-31). The responsibilities of the MPC also included conducting classes with the staff of relevant social education institutions to train them to understand the nature of defective children and the development of «methods and manuals» (Code of Laws, 1922, p. 31). MPCs were operating until the early $1930 \mathrm{~s}^{3}$ having a significant regional impact on the identification of special children, the introduction and dissemination among educators of a pedological approach to their study and learning. It contributed to the implementation of innovative, socially significant and humanistic ideas of education individualization in Ukraine (Hladush, 2011).

Thus, the representative of the Odesa MPC, Professor M. Tarasevych in 1922 developed and applied one of the first scientific classifications of children with mental and physical disabilities. According to the modern researcher O. Taranchenko, it had been done before L. Vygotskyi's conception was introduced (Taranchenko, 2006, p. 48).

\footnotetext{
${ }^{3}$ In the 1930s, in Ukraine, instead of MPCs, medical and pedagogical commissions were set up at public education departments to examine children with disabilities (or learning difficulties) and, if necessary, they were redirected to appropriate specialized educational institutions or for treatment. In the $1990 \mathrm{~s}$, such commissions were called psychologicalmedical-pedagogical consultations (PMPCs). Since 2017, in accordance with the idea of introducing inclusive education in Ukraine, a network of inclusive resource centers (IRCs) has been created, which replaced PMPCs, finally liquidated on September 1, 2018. IRCs are being built as fundamentally new institutions designed to identify special children's educational needs on the basis of the international classification of diseases, as it was before, but based on the international classification of the functions of special children.In addition, these centers should be more territorially accessible, because they are created with the assumption to have one center for no more than 7 thousand children living in a united territorial community (a district), and no more than 12 thousand children living in a city (a district of a city) (Inclusive education. Statistics; Inclusive resource center). IRCs are designed to ensure the «realization of the right of children with special educational needs aged 2 to 18 to receive preschool and general secondary education, including at vocational education institutions and other educational establishments that provide general secondary education, by conducting a comprehensive psychological and pedagogical assessment of the child's development, psychological and pedagogical, the provision of correctional and developmental services and systematic qualified support» (Inclusive education. Statistics). As of April 2019, 557 IRCs were registered in Ukraine (Inclusive resource center).
} 
M. Tarasevych developed his conception based on the statement that a person's physical and mental underdevelopment is not only a biological but also a social phenomenon, because disorders affect the formation of the child's personality as a whole. He also argued for the importance of careful, systematic study of a child («the initial registration of pedagogical phenomena») using the «statistical method for further understanding, consideration and regulation of external influences» (Tarasevych, 1923, p. 34-35).

And the representative of the Katerynoslav MPC (now in Dnipro), doctor-pedologist I.Levinson substantiated the need for differentiation of special children in the psychiatric and pedagogical aspect.

Emphasizing the importance of distinguishing between mental retardation and mental instability associated, in his opinion, with moral defects («It is selfish children, with a complete lack of awareness of public interests and the rights of others»), I. Levinson believed that in the fight against childhood defects an emphasis should be placed on «children who are on the verge of imbecility and mental retardation, because they have talents although they are limited and poorly capable of conscious generalizations» (Levinson, 1923, p. 151).

He argued that special children were more likely to become «street children» in the ranks of criminals and prostitutes being driven not only by difficult external circumstances of life, but also by their mental instability or imbalance (vague feelings, difficulties in abstraction, poor memory, etc.) (Levinson, 1923, p. 153-154).

He stressed the need to apply specific medical and pedagogical methods to such children closely monitoring them to identify children with mental disabilities in order to more accurately apply compensatory correction, and for the further deep individualization of educational influences to promote the development of such individuals and, first of all, their attention, moral feelings, the systematization of the motor sphere, the suppression of selfish desires and the formation of labor skills (Levinson, 1923, p. 160-162).

Sharing H. Troshyn's ideas, I. Levinson was a supporter of the creation of a large number of special institutions, different for each psychopathological category of children (as, for example, in Brussels, there are Demur's schools - for pedagogically neglected, foolish, undisciplined children and those with organic defects of speech (Levinson, 1923, p. 164) and special institutions «semi-prisons and semi-hospitals for people who due to unfortunate circumstances became criminals» (Levinson, 1923, p.159).

Official documents showed that the scientists' opinions had not gone unheard by the authorities. From the legislative and instructive materials of the USSR in the mid-1920s, in particular from the «Operational 
Plan of the Department of Social Education (Uprsotsvykh) of the PCEs of the USSR for 1925-1926» it was clear that in state documents there was a separate section «Special needs school», which was about the feasibility of «creating a network of special needs schools» (Operational plan for the period of 1925-1926, 1926, p. 41) to provide education to children with learning difficulties and with mental problems.

Based on the Western European methods of statistical calculations, according to which children in need of a special needs school comprised $3 \%$, for Ukraine at that time the determined number was more than 50,000 people (Operational plan for the period of 1925-1926, 1926, p. 41).

The document also singled out the category of children who «are between the norm and pathology and who cannot be called abnormal in the literal sense» (Operational plan for the period of 1925-1926, 1926, p. 42), but when they get to a mass (general - note) school, they block «the normal course of the educational process». The authors of the document emphasized that at the end of the XIX century, in Western Europe, and later in Russia, special classes at schools and separate schools for such children began to be organized but «in Ukraine, the network of such schools not only was not developed since 1914, but also the small number of those schools that existed before the war $^{4}$ in Kyiv and Kharkiv disappeared by 1922» (Operational plan for the period of 1925-1926, 1926, p. 42). Therefore, recognizing at the state level the need for special classes in regular schools, it was considered «necessary to start organizing special needs classes next year, and in large centers and schools for about 7,500 children» (Operational plan for the period of 1925-1926, 1926, p.42). But due to the lack of funding, there was a slow realization of this task.

In Kyiv, the MPC was called the «Cabinet of Individual Pedagogy» (CIP). Under the guidance of Professor A. Vladimirskyi, it carried out scientific and practical management of the orphan home for the blind (79 people), 2 orphan homes for the deaf and dumb (the Ukrainian orphan home named after Lagovskyi for 82 children and the Jewish one for 50 children), schools for the deaf and dumb (50 people), 50 special needs groups of children (104 people), the collector of mentally retarded children (52 people), 3 orphan homes for mentally retarded children (150 people) (Vladimirskyi, 1927, p.143-144).

It should be noted that in the CIP terminology the term «defective children» is rare (as opposed to the terminology used in theOdesa or

\footnotetext{
${ }^{4}$ the First World War
} 
Katerynoslav MPCs), the phrase «children requiring individual education» was used instead (Burkhart, 1929, p.42).

The activity of the Kharkiv MPC was, first of all, connected with the achievements of Professor I. Sokolianskyi in the field of experimental research of special childhood and his achievements in the study of deaf children. He developed a scheme of the medical, psychological and pedagogical examination of an abnormal child (Tumalevych, Ulanova \& Prokhorova, 1927). The system of conditioned behavior and the chain technique developed by him were covered in the articles «On the so-called lip reading of the deaf and dumb» (1926), «Towards the classification of stimuli» (1926), «Articulation schemes in the receptor language of the deaf and dumb» (1927). These works brought him a world's recognition. The scientist designed a reading machine for the blind, which is still used in teaching blind children.

I. Sokolianskyi also worked at the Ukrainian Research Institute of Pedagogy (URIP), established in 1926 also in Kharkiv, where he headed the «section of personality pedagogy (with defectology)» (Popiv, 1929, p.132, 133)). It is worth noting that the title of the section reflects the understanding of defective childhood as the existence of persons with individual personality traits rather than disabilities. The representatives of the Kyiv MPC also shared the same view on special children.

The above-mentioned URIP section took care of the only orphan home in Ukraine for blind and deaf children with a clinic functioning on its basis, where unique research and experiments on the adaptation of such children to life were conducted. I. Sokolianskyi with a small group of graduate students «conducted extremely valuable colossal scientific work» with the methods of its organization» (Popiv, 1929, p. 133) to study the individual's behavior. Actually, for I. Sokolianskyi, it was further work with deaf-mute children begun in 1910 in Alexander school-farm for the deaf and dumb in the Katerynoslav region.

In addition to the four MPCs, the Ukrainian Psycho-neurological Institute (UPI) was established in Kharkiv in 1922, which became the center of scientific and practical activities, including in the field of psychoneurological pedology in the Ukrainian SSR. It was responsible for the organization and development of a special psycho-neurological network of children's institutions - schools-sanatoriums for psycho-neurotics, schools-hospitals for children with epilepsy, schools-departments for mentally ill children and children with deep mental retardation at psychiatric hospitals, psychiatric labor colonies for antisocial psychopaths, speech therapy schools, etc. (Quint, 1929, p.154]. In this way, there was further differentiation of abnormal children in order to provide them with 
necessary medical and correctional care in a specially organized healtheducational environment.

One of the UPI units - the Cabinet of Medical and Pedagogical Examination (hereinafter - CMPE) - was engaged in «removal from normal children's institutions of special children» (Quint, 1929, p. 152) and determined what other institution a child should be transferred to. The responsibilities of the Cabinet included the implementation of psychoneurological examination and counseling on various issues of the» upbringing of the troubled youth «that teachers, educators and parents faced with in school and out-of-school environment» (Quint, 1929, p. 150).

The purpose of CMPE's research work was to address the issues of social and biological factors that «determine the exclusivity of children in terms of both sub-norms and super-norms, as well as to develop new methods for studying the personality and behavior of the child, and a number of other issues arising in the activities of children's institutions and health authorities to ensure the neuro-mental health of the growing generation» (Quint, 1929, p. 151).

Studying the behavior of mentally ill children in a pedagogically organized environment in a system of purposeful medical and pedagogical influences, scientists gained new important knowledge about the mental status of the person, which gave grounds for justification of the idea of children's differentiation and the application of educational influences and learning forms.

The activities of Ukrainian pedological-pedagogical and medicalpedagogical state institutions focused mostly on the primary differentiation of the child population on the basis of its examination and identification of persons with normal and abnormal development, also consisted of:

- purposeful development of medical and pedagogical support and laying the foundations of the scientific and pedagogical study of abnormal children, which contributed to the formation of the domestic branch of pedagogy - defectology.

- development of recommendations on education organization and socialization adequate for the peculiarities of children and adolescents' development and abilities;

- dissemination of new psychological and pedagogical ideas among teachers and educators and treatment of an abnormal child not only as a person who needs care only, but also as a person with their own individual and social needs, who can and should be socialized.

Due to the scientific research, primarily by MPC and UPI representatives, in Ukraine, a professional division in the training of specialists in the areas of children's developmental anomalies was gradually 
introduced - deaf education, pedagogy for blind and visually impaired, oligophrenopedagogics.

The development of the differentiation of abnormal children into categories in terms of establishing the degree of their defects in the implementation in the USSR in the 1930s of general education (mass education) was socially significant and most importantly - human-centered. Thus, the resolution «On the introduction of general compulsory education for physically defective, mentally retarded and speech-impaired (speech therapists) children and adolescents» (1931) and its annex provided explanations for distinguishing the categories of the deaf and the hard of hearing. The hard of hearing were further divided into three categories, depending on the degree of deafness - mild, moderate, severe. Since the education of children with these disabilities was planned within secondary schools, the pedagogical work with them was based on general didactic principles. But at the same time, recommendations were developed for teachers to take into account the characteristics of such students, who also had to attend short courses on «face reading and speech correction» and be under the constant supervision of an otolaryngologist (Taranchenko, 2006, p. 49).

In the course of the implementation of mass primary education, the differentiation of the education of special children began to expand: first of all, an attempt was made to cover the education of all children with hearing disorders; on the basis of existing diagnostic approaches, the hard of hearing were separated from the deaf and mentally retarded children, the hard of hearing were taught in separate classes, which increased the efficiency of education and the possibility of full-fledged socialization.

The activity of scientific state institutions newly created in Ukraine, which were engaged in the study of special children, laid the foundation for the purposeful development of medical and pedagogical support for the various groups of children contributing to the scientific study of special children. The main thing is that both in the educational environment and in society, the humanistic ideas of treating a special child not only as a person who needs care, but also as a person with their own individual and social needs who can and should be socialized have become widespread.

It is undeniable that the approach to the development of the education system declared in Ukraine in the 1920s was focused on the humanistic consideration of the diversity of children's characteristics and ensuring the social interests of all the categories of children. At that time, it was socially and pedagogically expedient to create special separate educational institutions for special children, where they could be provided with medical and rehabilitation care, as well as certain knowledge about their 
abilities, the state of health, and some work skills necessary for further socialization.

Besides, due to the objective difficulties of the first postwar years, the communist authorities in Ukraine failed to implement the declared intentions to transform education and implement all initiatives. The creation of a network of boarding schools for special children at that time had no alternative and was a social achievement.

The renewal of education in Ukraine in the 1920s in the spirit of socialism, the development of new approaches to the organization of the life and education of children and adolescents was in line with European trends in child protection - both normal and defective ones, i.e. on the basis of combined efforts of teachers and physicians. Objective social factors - the existence of a huge number of orphans and homeless people after the war, the growth of juvenile delinquency, complex material and economic difficulties did not allow for carrying out innovative initiatives. However, they confirmed the unconditional desire of the early Soviet authorities in Ukraine to implement the best achievements of the European pedological thought.

\section{References}

Azin, V.O., Baida, L. Yu. ...\& Fletcher, A. (2015). Nothing for us without us: A guide to inclusive decision-making for public authorities. Kyiv: Lenvit.

https://www.britishcouncil.org.ua/sites/default/files/toolkit_pm_ukr.pdf

Bondar, V., Zolotoverkh, V. (2004). Interpretation of the evolution of special education: origin, formation, development (to the tenth anniversary of the Institute of Special Pedagogy of the Academy of Pedagogical Sciences of Ukraine). Defectology, 1, 2-10.

Bondar, V.I. (1992). Development of the theory and practice of vocational training of special needs school students in Ukraine (1917-1990): abstract of a doctoral thesis in pedagogy : 13.00 .03 «Special pedagogy». Kyiv.

Bondar, V.I. (2015). Theory and history of educating children with intellectual disabilities. Sinov, V.M., Bondar, V.I Educational Integration of students with Intellectual Disorders. Study guide. (pp. 6-65). Kyiv: View of the National Pedagogical Dragomanov University publishing.

Burkhart, Ju. L. (1929). Cabinet of Individual Pedagogy of the Kyiv Experimental Pedological Station. The path of education, 8-9, 142-146.

Vladimirskyi, A., prof. (1927). Cabinet of individual pedagogy in Kyiv. The path of education, 10, 144-147.

Hladush, V.A. (2012). Trends in the development of the theory and practice of special educators' postgraduate education in Ukraine (1950-1990). Collection of 
Trends and Prospects of the Education System and Educators' Professional ...

scien. works of Kamianets-Podilskyi National Ivan Obiienko University: ser. Sociopedagogical. Kamianets-Podilskyi: Medobory-2006, 19/1, 59-69.

Hladush, V.A. (2011). On the issue of periodization of the development of special educators' postgraduate education in Ukraine (the second half of the XX-early XXI centuries). fkspp.at.ua/konf/Uch2/5.pdf

Dichek, N.P. (2013). Medical and pedagogical cabinets as leaders of ideas of reforming the pedagogical process in Ukraine (1920s). In V. Kremen, T. Levovytskyi, V. Ohneviuk (Ed.). Educational reforms: mission, reality, reflection: monograph. (pp. 429-454). Kyiv.

Dichek, N.P. (2013). The contribution of domestic experimental pedagogy in substantiating the need for individualization and differentiation of the educational process. Differentiated approach in the history of the Ukrainian school (end of the XIX - first third of the XX century). Kyiv: Ped. dumka.

Law of Ukraine «On Amendments to Certain Legislative Acts of Ukraine Concerning Social Protection of Persons with Disabilities». https://xn-80aagahqwyibe8an.com/ukrajiny-zakony/zakon-ukrajini-pro-osnovisotsialnoji1991.html

Inclusive education. https://mon.gov.ua/ua/tag/inklyuzivne-navchannya

Inclusive education. Statistics. https://mon.gov.ua/storage/app/media/inkluzyvne-navchannya/statistikainklyuziya.pdf

Inclusive resource center. http://ircenter.gov.ua/

Quint, L. (1929). The activity of the Department of Child. Psycho-neurology Ukr. State. Psycho-neurological Institute in connection with the main tasks of recreational activities. The path of education, 8-9, 154-156.

Code of Laws on Public Education of the Ukrainian SSR (1922). Kharkiv: Publication of the People's Commissariat of Education of the Ukrainian SSR.

Kozlov, I. (1928). Reflex-ortho-pedagogy. Ukr. Bullet in experiment. pedagogy and reflexology, 1 (8), 122-146.

Convention on the Rights of Persons with Disabilities. https://zakon.rada.gov.ua/laws/show/995_g71

Kravchenko, I.V. (2016). Historical and pedagogical aspects of the development of special education in Ukraine. Pedagogical sciences: theory, history, innovative technologies, 1 (55), 364-371.

Levinson, I. (1923). Troubled children and the fight against child defects. The path of education, 2, 151-162.

Lukianova, V.A. (2002). Development of experimental pedagogy in Ukraine (the 20-30s of the $X X$ century): abstract of a $\mathrm{PhD}$ thesis in pedagogy. Kharkiv.

Operational plan for the period of 1925-1926 (1926). General education in the USSR: legislative and instructional materials, Part 1. Kharkiv: DVU, 34-48. 
Popiv, O.I. (2003). Declaration of the People's Commissariat of Education of the USSR on the social upbringing of children. Little-known primary sources of Ukrainian pedagogy (second half of the XIX-XX centuries): textbook. Kyiv: Scientific World, 237-240.

Popiv, O.I. (1929). Ukrainian Research Institute of Pedagogy in Kharkiv. The Path of Education, 8-9, 129-135.

Protopopov, V.P. (1928). The problem of the formation of behavioral science. Ukr. Bulletin of experimental pedagogy and reflexology, 1 (8), 189-197.

Suprun, M.O., (2005). Correctional education of students of special needs educational institutions: origins, formation and development (second half of the XIX - first half of the XX century). Kyiv: Publisher PALYVODA A.V.

Taranchenko, O. (2006). Periods of the formation and development of the system of special education for children with hearing disorders in Ukraine. Defectology, 3, 47-52.

Tarasevych, N. (1923). About scientific and pedagogical work in children's institutions of Sotsvos. Our school, 4-5, 31-35.

Tumalevych, Je.A., Ulanova L.I., Prokhorova O.I. (1927). Organization of initial skills in deaf blind children according to the system of conditioned behavior and the chain method of I.P. Sokolianskyi. Ukr. bulletin of expert. ped. and reflexology, 1 (4), 48-123.

What is inclusive education. https://mon.gov.ua/ua/tag/inklyuzivne-navchannya

Yarmachenko, M.D. (1975). History of deaf education. Kyiv: Higher School. 